\title{
Integrated reporting:
}

Background, measurement issues, approaches and an agenda for future research

Charl de Villiers

The University of Auckland and University of Pretoria

charl.devilliers@auckland.ac.nz

\author{
Elmar R. Venter \\ University of Pretoria \\ elmar.venter@up.ac.za \\ Pei-Chi Kelly Hsiao \\ The University of Auckland \\ k.hsiao@auckland.ac.nz
}

\section{Please cite as:}

De Villiers, C., Venter, E. \& Hsiao, P. 2017. Integrated reporting: Background, measurement issues, approaches and an agenda for future research, Accounting \& Finance, 57(4), 937-959.

\begin{abstract}
We discuss the background to integrated reporting, a new reporting framework focused on firms' future value creation narrative. We consider why integrated reporting is an area of interest for the accounting profession, accountants, investors, regulators, and managers. We provide an overview of the integrated reporting literature, discuss measurement and research design issues to take into account when designing studies on integrated reporting, and identify approaches and set an agenda for future research.
\end{abstract}

Keywords: Integrated reporting; IIRC; Research agenda 


\section{Introduction}

Integrated reporting is a new reporting framework that proposes the integration of financial and non-financial information in a single report. It incorporates new ideas on reporting that could change the corporate reporting landscape, improve investors' ability to assess firms' future prospects, and provide solutions to overcome the oft-repeated criticisms of traditional accounting reporting models. Integrated reporting is promoted by the International Integrated Reporting Council (IIRC), a body with widespread international following and support, as well as by the IIRC's adherents, which include regulators and the accounting profession. According to the IIRC (2013), integrated reporting (IR) should involve a concise report that articulates an organization's future value creation plans, referring specifically to the organization's strategy, business model, and various forms of capital (financial, manufactured, intellectual, human, social and relationship, and natural capital). The IIRC hopes that IR will engender a longer-term focus among managers and investors, replacing the short-termism often blamed for several of the ills of capitalism (and of accounting).

The rapid spread of IR and the large number of firms that already produce, or plan to produce, an integrated report is a testament to the persuasiveness of the IIRC's argument regarding the benefits of IR. It may also indicate that IR suits the needs of our time. IR was already discussed, and emerged as a reporting practice, before the advent of the IIRC. For example, in 1999, PwC introduced its "Value Reporting Framework", which initiated the debate around IR. In 2002, Novozymes (a Danish enzyme company which is a spin-off from the healthcare firm Novo Nordisk) issued the first integrated report, shortly followed by Novo Nordisk's own integrated report. The global financial crisis that followed soon after led to closer scrutiny of traditional accounting and reporting models, as their shortcomings were 
implicated in the crisis, and are sometimes blamed for them. This led to calls for greater integration of financial and non-financial disclosures.

The rapid implementation of IR has been accompanied by a growing body of academic literature, for example, studies by Atkins et al. (2015), Atkins and Maroun (2015), Serafeim (2015), and Stent and Dowler (2015). Many of the initial studies advocated or criticised IR, or provided normative advice on how to implement IR. These initial IR studies were followed by empirical studies using case studies, interviews or content analyses. A few studies have also investigated the country-level determinants of IR adoption and implementation. IR is a recent development, therefore limited time series data are available. Nevertheless, economics-based evidence is beginning to emerge regarding the positive economic consequences associated with IR. The evidence thus far consists mostly of unpublished working papers (e.g. Barth et al., 2015; Bernardi and Stark, 2015). Given the preliminary nature of the studies and their findings, the IR measures used and the research design choices of these studies are open to critique, and there are several opportunities for further research.

For instance, the IIRC $(2013$, p. 2) claims that IR aims to "improve the quality of information available to providers of financial capital to enable a more efficient and productive allocation of capital" and "support integrated thinking, decision-making and actions that focus on the creation of value over the short, medium and long term". Whether IR delivers on these promises remains an empirical question that can be divided into three sub-questions: (1) Are there positive economic consequences associated with IR?, (2) How do investors react to various forms and formats of IR?, and (3) How do organizations adapt internally to cope with the demands of IR? A fourth intuitive question relates to the diffusion of IR: (4) How is the field of IR developed by the accounting profession and by the IIRC? 
In addition to the emerging empirical evidence on IR, there are a few overview and agendasetting articles, for example De Villiers et al. (2014). However, these overview articles do not discuss the issues specific to economics-based research. Therefore, while we discuss the whole range of prior literature, we specifically elaborate on the challenges facing economicsbased IR researchers.

\section{Background to the International Integrated Reporting Council (IIRC) and IR}

In reaction to dissatisfaction with the then current corporate reporting models, the Global Reporting Initiative (GRI) and the Prince of Wales' Accounting for Sustainability Project formed the IIRC in 2010. The aim was to get both managers and providers of financial capital to consider the long-term consequences of a broader set of capitals. Therefore, although individuals in the social and environmental sustainability sphere played an important role in the founding of the IIRC, the IIRC's framework, published in December 2013, emphasise future value creation for financial stakeholders (IIRC, 2013).

The IIRC framework is principles-based and is only 37 pages long. It is left to managers' discretion to apply the IR principles. The principles-based approach to IR creates difficulty in the assurance, regulation and research of IR, because it is difficult to determine whether, and to what extent, a firm complies with the IIRC framework.

The IIRC framework provides seven guiding principles and eight content elements for integrated reports that point towards the need for integrated reports to be concise, include both financial, non-financial, and qualitative information, and to not merely summarise existing reports, but to be an "identifiable communication... which may be either a standalone report or be included as a distinguishable... part of another report" (IIRC, 2013, p. 8). IR tells a firm's value creation narrative going forward, by specifically referring to corporate strategy, how the strategy translates into a firm's business model, and how the 
business model takes advantage of the six forms of capital (financial, manufactured, intellectual, human, social and relationship, and natural capital) to create or destroy value. "Integrated thinking" is meant to facilitate high quality IR by promoting a long-term outlook.

Based on the intended characteristics of an integrated report and the fact that financial statements are subject to well-established regulation, integrated reports cannot replace mandated financial reports, or provide all the information that is of interest to firms' nonfinancial stakeholders. Therefore, it may still be necessary for firms that are preparing an integrated report to produce a separate financial report to comply with mandatory requirements, and other stand-alone reports aimed at other stakeholders.

Firms apply various titles to stand-alone reports directed at non-financial stakeholders, including "environmental", "social", "sustainability", and "corporate social responsibility" (CSR) reports. These reports are also referred to as GRI-inspired reports, as the GRI provides a framework for these kinds of disclosure. Such reports are also increasingly known as environmental, social and governance (ESG) reports, because the Bloomberg business information service provides environmental, social and governance data on individual firms, referring to the information as ESG information. Moreover, by 2017, a European Commission directive will require firms with more than 500 employees to disclose ESG information. Some firms produce a lengthy report that includes their statutory financial statements and a sustainability report, which they entitle an "integrated report" or a "one report". These reports either contain elements of a "high quality" integrated report or is merely a relabelled combination of previously issued stand-alone reports.

The IIRC actively promotes IR by means of roadshows to universities, regulators, and corporates. It also involves CEOs and other influential individuals and organizations on various boards and activities. For instance, the Corporate Reporting Dialogue (the Dialogue) 
is an initiative formed to improve the current state of corporate disclosure. Participants include the United Kingdom's Carbon Disclosure Project, the Climate Disclosure Standards Board, the Financial Accounting Standards Board, the GRI, the International Accounting Standards Board, the International Organization for Standardization, and the United States' Sustainability Accounting Standards Board. ${ }^{1}$

Since the IIRC framework's release in 2013, IR has attracted interest at every level across the globe, from regulators, firms, preparers and investors. At the international level, the European Commission (EC, 2014) and Business 20 (B20, 2014) have acknowledged the importance of and need for IR concepts. ${ }^{2}$ At the country level, Australia (Kitney, 2014), Japan (Kee et al., 2014), India (Business Standard Reporters, 2014), and Singapore (Kee et al., 2014) have either begun to adopt IR or have expressed strong intentions to get firms to do so. At a firm level, more than 100 multinationals, including the Coca-Cola Company and Microsoft Corporation, have voluntarily participated in the IIRC's pilot programme. GE, one of the world's five largest firms, issued its first integrated report in March 2016 (Fairfield, 2016).

\section{Literature review}

For the purposes of our literature review, we identified IR literature by searching Google Scholar, the Social Sciences Research Network (SSRN), Scopus, and other university library, e-journal, and publishing databases. We focus on and include articles published in highly ranked accounting and finance journals, other articles with a high number of citations, as well as recently published articles that offer new insights. ${ }^{3} \mathrm{We}$ exclude articles that provide no new insight or that cover familiar ground. In this review, we identify themes that we use to

\footnotetext{
${ }^{1}$ See "Navigating the corporate reporting landscape", available at: http://corporatereportingdialogue.com/wpcontent/uploads/2015/05/CRD-Mapping-Document_website_070515.pdf.

${ }^{2} \mathrm{~B} 20$ is a group of business leaders from large companies which tries to influence governments of the G20.

3 We include all IR articles published in A and A* accounting and finance journals, as rated by the Australian Business Deans Council. We add all articles and other sources that have been cited at least 10 times at the time of our searches, except where this material does not add any new information.
} 
organise the remainder of the section. Early papers on IR generally advocate the practice or are normative, providing advice around implementation. More recent articles focus on empirical research. We organise our literature review according to the following themes: advocacy, critique, normative, case studies, investor views, IIRC activities, content analyses, country-level determinants, and economics-based archival studies.

The IIRC's early discussion papers emphasised firms' sustainability and accountability to a broader group of stakeholders. The final IIRC framework identifies providers of financial capital as the primary user group of integrated reports. Some of the studies we discuss used the original conception of IR as a stakeholder-centric reporting mechanism, instead of the IIRC's final investor-centric logic. Therefore, the statements made and the conclusions drawn would differ, depending on whether the authors used an investor focus, which is likely to prevail in future research.

\subsection{Advocacy}

Early advocates of IR believed that encouraging a long-term and sustainable orientation will benefit both corporations and stakeholders. Integrated thinking and reporting is often promoted as a practice that leads to better internal decision-making, lower reputational and regulation risk, and greater corporate transparency, simultaneously strengthening financial stability and contributing to a more sustainable society (Eccles and Krzus, 2010; Eccles and Saltzman, 2011; Krzus, 2011). The not-for-profit sector can apparently also benefit, because IR provides strategic information that is important in terms of acquiring competitive funding (Adams and Simnett, 2011).

This literature highlights challenges, such as the lack of a globally accepted standard for measuring and reporting non-financial information, and the variability of the relevance, applicability and adoption of IR across jurisdictions (Adams and Simnett, 2011; Eccles and 
Saltzman, 2011; Eccles and Serafeim, 2011). Therefore, integrated reports are not always comparable, potentially reducing their usefulness to investment analysts. Nevertheless, Eccles and Serafeim (2011) argue that IR is urgently needed to address issues such as natural resource limitations and financial stability, and encourage regulatory bodies to mandate IR.

\subsection{Critique}

The IIRC framework has been criticised for diverging from the IIRC's roots in sustainability and accountability to stakeholders (Brown and Dillard, 2014; Cheng et al., 2014; Flower, 2015; Thomson, 2015). Flower (2015) argues that investors and society value different things. Investors require financial information regarding future profitability, whereas society arguably require broad-based information irrespective of corporate interest. Flower (2015) anticipates that IR will have little effect on underlying corporate practices. Similarly, Brown and Dillard (2014) hold that IR has become focused on stakeholder management rather than on stakeholder accountability, reinforcing business-as-usual. Moreover, it may be difficult to achieve social and economic sustainability by privileging financial stakeholders.

On the basis of interviews with various stakeholder groups, Van Bommel (2014) reports that stakeholders hold different views on what IR should emphasise to gain legitimacy in society. Van Bommel (2014) claims that the current state of IR generates bias instead of a legitimate compromise. Other problems with the IIRC's framework arise from ambiguity surrounding the meaning(s) and assessment of capitals, and complexities regarding the assurance of integrated reports (Cheng et al., 2014).

In defending the IIRC framework, Adams (2015) explains that the focus on value creation for capital providers is a result of the diversity and discrepancies in the meaning(s) of "value creation" to different stakeholder groups. Adams (2015) suggests the main purpose of IR is not to address sustainability, but rather to encourage a different way of thinking about profit 
maximization and corporate success. However, IR's strong market orientation may have resulted from a lack of stakeholder engagement in the framework's development, implying that the IIRC's framework fails to reflect report users' information needs and may be less applicable to different organizational forms or countries in different stages of economic development (Reuter and Messner, 2015).

\subsection{Normative}

Ideas to promote IR have begun to emerge from the academic community. For instance, Abeysekera's (2013) IR template suggest that reports should be less than ten pages long, and should be inclusive of all corporate stakeholders. Moreover, report contents should be a combination of narrative, numerical, and visual information to communicate a holistic organizational picture. In another example, Rambaud and Richard (2015) proposed a "Triple Depreciation Line" accounting model, aimed at the maintenance of both financial and nonfinancial capital.

\subsection{Case studies}

Case study or interview based approaches have started to provide initial insights, e.g. Knauer and Serafeim (2014) found evidence that engaging in integrated thinking and reporting, backed up by enhanced transparency and ESG performance, attract long-term investors.

Parrot and Tierney (2012) focus on the difficulties of balancing financial and ESG considerations, as well as multiple stakeholder interests. IR's long-term perspective encouraged managers to embrace the complexity of balancing multiple dimensions.

A number of studies examine early adopters in Australia, providing insight into the institutionalization of IR. Higgins et al. (2014) interviewed Australian managers, revealing ambiguities. Managers are unsure whether IR is a change in reporting format, or represent a 
change in the nature of reporting. Managers perceive IR to be more about story-telling and meeting institutional expectations. IR does not apparently encourage change to corporate norms. Similarly, Stubbs and Higgins (2014) found no evidence that IR practices stimulate innovations in reporting processes. Instead, IR was considered an extension of sustainability reporting. Lodhia's (2015) results show that in a customer-owned business (a bank), the following enable IR implementation: recognition of the potential value of IR; practice guidelines; a value system based on economic, social and environmental considerations; and an organizational structure that integrates economic, social and environmental responsibilities.

\subsection{Investor views}

The institutional investment community is increasingly considering ESG information to be financially material in nature (Atkins et al., 2015; Atkins and Maroun, 2015), but there is still resistance from mainstream financial analysts to engage with ESG (Atkins et al., 2015). Atkins and Maroun (2015) show that South African institutional investors consider integrated reports to be an improvement on traditional annual reports, but note variance in disclosure quality, lengthy reports, repetition, and a box-ticking approach to reporting. Institutional investors consider IR to fit a stakeholder focus, emphasise substance over form, and a need for assurance. Atkins and Maroun (2015) also report that institutional investors associate IR with managements' desire to portray a favourable corporate image.

\subsection{IIRC activities}

Recent studies have explored the methods the IIRC uses to promote its agenda (Humphrey et al., 2016; Rowbottom and Locke, 2016). 


\subsection{Content analyses}

Research based on content analysis often assesses the quality of integrated reports. Eccles $e t$ al. (2015) and Solomon and Maroun (2012) suggest a need for more detailed disclosure regarding: stakeholder identification and prioritization, the materiality assessment process, and more forward-looking information regarding ESG performance. Eccles et al. (2015) report that manufacturers highlight the goal of lowering resource consumption by linking strategy to product innovation, whereas non-manufacturing firms tend to associate strategy with human capital development or customer value creation. Adopting a different perspective, Stent and Dowler (2015) identified only a slight difference between the disclosures of New Zealand's best reporting entities and IR principles. Stent and Dowler (2015) call for improvements in connecting information, reporting on uncertainties in future outlook, and reporting against industrial or regional benchmarks.

\subsection{Country-level determinants of IR adoption}

Evidence suggests that institutional and cultural factors influence the adoption of IR. According to Jensen and Berg (2012), the probability of firms' preparing integrated reports are higher for countries with higher investment protection laws, private expenditure on tertiary education, levels of self-expression, and greater market coordination. Frías-Aceituno et al. (2013) found that firms operating in civil law countries are more likely to prepare integrated reports. In terms of Hofstede’s cultural dimensions, García-Sánchez et al. (2013) suggest that integrated information is more likely to be provided by firms operating in more feminist and collectivist cultures. 


\subsection{Economics-based archival studies}

There are currently few capital markets studies on IR, as it is a recent phenomenon with limited archival data. Therefore, we broadened our literature search to include conference and working papers. As the research questions and the related issues we identify overlap across articles, we do not discuss them all (e.g., excluding Arguelles et al., 2015; Churet, and Eccles, 2014; Lee and Yeo, 2015; Maniora, 2015).

Most of the archival studies use South African data, mainly because since March 2010, IR has been required on an "apply or explain" basis for firms with a primary listing on the Johannesburg Stock Exchange (JSE), in terms of the King Code of Governance for South Africa (King III) (IoD, 2009). ${ }^{4}$ Therefore, South Africa is the most suitable mandatory IR setting. Note that the characteristics of the JSE as a market (for example, in terms of liquidity, market reaction, etc.) are similar to those of developed country bourses.

Barth et al. (2015) and Zhou, Simnett and Green (2016) investigate the economic consequences associated with integrated report quality (IRQ) in South Africa. Zhou, Simnett and Green (2016) use a sample of South African firms and include observations from the periods before and after the effective date of the JSE's "apply or explain" regulation, while Barth et al.'s (2015) only considers data from after the implementation of the regulation. Zhou, Simnett and Green's (2016) findings show that analysts' forecast error is lower when IRQ is higher, but they report no clear association between IRQ and forecast dispersion. Their cost of capital tests provides partial evidence to suggest a negative association between IRQ and cost of capital only for firms with a low analyst following. Barth et al. (2015) report

\footnotetext{
${ }^{4}$ Integrated reporting has been required for firms listed on the JSE since March 2010. The regulation adopts an "apply or explain" approach in recognition of the fact that often it is not a case of whether to comply or not, but rather of considering how the principles and recommendations can be applied (IoD, 2009). In other words, disclosure on the application of integrated reporting is mandatory, but "the board of directors, in its collective decision-making, could decide to apply the recommendation differently or apply another practice and still achieve the objective of the overarching corporate governance principles of fairness, accountability, responsibility and transparency. Explaining how the principles and recommendations were applied, or if not applied, the reasons, results in compliance" (IoD, 2009:6).
} 
that IRQ is positively associated with both stock liquidity (using bid-ask spreads as a measure) and firm value (using Tobin's $Q$ as a measure). When firm value is decomposed into an expected future cash flow effect and a cost of capital effect, the positive association between IRQ and firm value is driven mainly by the cash flow effect (Barth et al., 2015).

Baboukardos and Rimmel (2016) and Bernardi and Stark (2015) have studied the effect on the market of the exogenous shock of making integrated reports mandatory. Bernardi and Stark (2015) report no association between ESG disclosure and analyst forecast errors prior to the IR regime. By contrast, they show a negative and statistically significant association between ESG disclosures and analyst forecast accuracy after IR became mandatory in South Africa, which is consistent with the IIRC's aims. Baboukardos and Rimmel (2016) assess the value relevance of financial accounting numbers (book value of equity and earnings) before and after the IR requirement in South Africa, finding that the earnings coefficient increases (supporting IIRC claims), whereas the net assets coefficient decreases (inconsistent with IIRC arguments).

Serafeim (2015) examines the composition of firms' investor base, using a sample of US firms 'practicing IR', which is really based on the 'Corporate Governance: Integration/vision and strategy" ("CGVS”) data item from the ASSET4 database. ${ }^{5}$ Appendix 1 provides more detail on CGVS. We assess the construct validity of this proxy in our section on “measurement issues" below. Serafeim's (2015) findings support the hypothesis that firms practising IR have a more long-term oriented investor base, with more dedicated and fewer transient investors. This result is more pronounced for firms with high growth opportunities, not controlled by a family, operating in "sin" industries, and exhibiting more stable IR practices over time. Moreover, he shows that investor activism on environmental or social

\footnotetext{
${ }^{5}$ ASSET4 is a division of Thomson Reuters which collects environmental, social and corporate governance data for over 6,000 firms globally. More than 750 individual data items are grouped into 18 categories within four pillars (economic, environmental, social and corporate governance performance).
} 
issues or multiple concerns about a firm's environmental or social impact lead a firm to practise more IR, and that this investor- or crisis-induced IR affects the composition of the firm's investor base. Serafeim's (2015) main results for US firms hold for a global sample of 97 firms, using a self-constructed proxy of IRQ. When decomposing IRQ into "content elements", "capitals" and "guiding principles", the association between "guiding principles" and long-term investor base is the strongest component.

Since integrated reports are prepared by managers, these reports are subject to agency problems, suggesting a need for the assurance of integrated reports (Hay, 2015). IR pose challenges to existing assurance mechanisms, especially external assurance, because the content is future-oriented, valuation-based, and broad. The IIRC has issued three papers on assurance, demonstrating the importance of the credibility of integrated reports. ${ }^{6}$ King III (IoD, 2009, p. 50) also introduces the concept of a "combined assurance model" - this entails "integrating and aligning assurance processes in a company to maximise risk and governance oversight and control efficiencies, and optimise over-all assurance to the audit and risk committee, considering the company's risk appetite".

Zhou, Simnett and Hoang (2016) show that the adoption of the combined assurance model in South Africa makes a difference to analysts' forecast accuracy and dispersion because it helps reduce information risk, reflected by a significant negative association with analysts' earnings forecast dispersion, after controlling for IRQ, suggesting that the combined assurance approach enhances the reliability of existing information, but fails to provide new information to assist analysts in forecasting more accurately.

\footnotetext{
${ }^{6}$ The papers are available on the IIRC's website under "resources". The three papers are (1) Assurance on IR: An introduction to the issues; (2) Assurance on IR: An exploration of the issues; and (3) Assurance on IR: Overview of feedback and call to action.
} 
In summary, these economics-based studies provide preliminary evidence that IR is associated with greater analyst forecast accuracy, lower cost of capital, higher stock liquidity, firm value and expected cash flows, and a more dedicated investor base. However, the evidence is subject to limitations inherent in sample selections, settings, and periods. Most of the evidence is based on the limited South African time-series data. Researchers will be able to explore these issues in more detail as more firms and countries adopt IR. Limitations related to setting could also be addressed through studies using data from other countries or data across countries, paying particular attention to whether IR adoption is mandatory or voluntary. In addition, the construct validity of the IR proxy used is important. We discuss issues around the research setting (country), data, and measurement below.

\section{Measurement issues to consider in IR research}

The nature of the IR framework (which requires firms to tell their value creation story while incorporating only the applicable elements in their report) has several measurement implications. The broad question is what characterises a high quality integrated report. A secondary question is how we can measure such quality. The fact that some firms merely relabel their glossy annual reports as integrated reports implies that the term "integrated report" is not sufficient evidence that a firm has adopted IR as envisaged by the IR framework. At the other extreme, firms may not label their reports as being integrated, even though the reports contain exemplary high-quality IR (EY, 2014).

It is therefore important to find a suitable proxy for "IR adoption" or "IR quality". Several databases now provide measures of social, environmental, and governance issues. For example, Bloomberg has its so-called ESG measures, and Thomson Reuters has ASSET4. Bloomberg markets its ESG data under the name RepRisk, suggesting that social, environmental, and governance data can be used for the purpose of assessing firms' risk of 
suffering reputational damage and financial losses. The KLD database provides social, environmental, and governance metrics for the top 3,000 US firms. Indirect proxies for IR can be constructed from these databases. The obvious advantage of using these databases is that measures can be generated for a large sample, whereas any form of hand collection of data inevitably involves sample size trade-offs.

With database-derived proxies, a number of considerations come to mind. Firstly, database providers cover a broad range of firms, irrespective of whether or not a firm has issued an integrated report. Secondly, such proxies can often be better described as social and environmental measures than as IR measures, especially given that coverage of more social and environmental aspects in disclosure does not necessarily equate to high quality IR. IR is meant to focus on the most important future value creation opportunities and address these in an integrated fashion. Thirdly, it is not entirely clear whether these measures can be used as disclosure measures - even though Bloomberg, Thomson Reuters and KLD are all based on firm disclosures, they also reflect information from other sources, such as news media, and private information obtained from firms. Therefore, these measures are often used in the literature as proxies for firms' CSR performance, not their disclosure. The voluntary disclosure literature often assumes a high positive correlation between performance and disclosure (as managers prefer to disclose only good news) (Healy and Palepu, 2001), but the CSR literature shows that environmental performance and environmental disclosure are significantly negatively correlated (De Villiers and Van Staden, 2011), as managers disclose more positive environmental news when there is negative information (De Villiers and Van Staden, 2011). Thus it is important to ensure the construct validity of IR disclosure proxies and to beware of proxies that measure performance rather than disclosure, or social and environmental disclosure instead of IRQ. 
Serafeim (2015) uses the CGVS data item from the ASSET4 database as a proxy for IR. We discuss the validity of this measure to demonstrate the difficulty of finding an appropriate measure in existing databases. In describing CGVS, ASSET4 refers to drivers and outcomes (see Appendix 1). All four drivers and two of the eight outcomes refer to "integration". The components of the drivers seem to capture whether integration is incorporated into managers' day-to-day decision-making. This seems to measure the level of "integrated thinking" in a firm (performance), rather than the quality of its integrated reports (disclosure). The first two outcomes of CGVS could capture certain aspects of the quality of an integrated report. For example, CGVSO02 measures whether financial and non-financial aspects are integrated in the management discussion and analysis (MD\&A) section of an annual report. Many firms that issue an integrated report do not have a separate MD\&A section, because the whole integrated report is a discussion and analysis by managers. Our check of the coding of CGVSO02 for the top 100 JSE-listed firms in terms of market capitalization on 31 December 2014 reveals that of the 91 firms with available data in ASSET4, 23 firms are coded as "yes" and 68 as "no". Given the mandatory IR regulation in South Africa, this coding is unlikely to be an accurate reflection of whether managers of South African firms integrate financial and non-financial aspects in their discussions in the integrated report. The remaining six outcomes of CGVS reflect reporting outcomes, but we do not believe that they capture the level of integratedness well, being more related to "integrated thinking" (performance) than to IR quality (disclosure). Nevertheless, Serafeim (2015) is an early study, explaining why a lesser proxy sufficed. Future studies will have to use better measures of IR adoption and quality.

Another approach is to use a measure of IR quality from an external source, such as a scoring system to award IR prizes. Barth et al. (2015) adopted this approach. In particular, they used the scores of the annual EY Excellence in IR awards as their proxy for IR quality. As with 
most proxies, the approach has both advantages and disadvantages. One advantage is that the coders (the adjudicators) are independent from the researchers. With the EY awards, the adjudicators are three professors from a leading South African university, with 46 years of combined experience in adjudicating corporate reports for EY Excellence awards. EY used the same adjudicators throughout Barth et al.'s (2015) sample period. The downside of using an external source is that researchers are restricted to the sample evaluated by the external source. At present there are few such awards, but judging by the CSR experience, there will be more in future.

Another direct approach would be to hand collect data using content analysis. Zhou, Simnett and Green (2016) took this approach. Their coding framework measured eight broad dimensions across 31 specific components, based on the IIRC's 2012 Prototype Framework. For some components, they assigned a fractional score to capture varying levels of IRQ. This coding approach is labour-intensive and so it is restricts researchers to relatively small sample sizes. Given the principles-based nature of IR and the importance of assessing the level of integration in a report, it is vital to use experienced coders with a solid understanding of the objectives of IR. Returning to the question of what constitutes a good integrated report and how to measure it, if an element mentioned in the IR framework is absent, does that mean the firm has neglected to disclose it, or does it mean the firm considered it and decided that it was not appropriate for the firm to disclose that element, as it is not a part of its value creation narrative? This question is critical in considering the disclosure framework and scoring used in any content analysis-based research procedure. A research agenda can be built around assessing hand collected IR proxies. 
Finding/designing an appropriate IR adoption or IRQ measure is an important step in designing an IR research project. In addition, the inclusion of appropriate control variables requires careful consideration, as we show below.

\section{Control variables and research design issues to consider}

In this section, we discuss control variables and research design issue to consider in an economics-based IR study.

Accounting researchers are often interested in the impact of (accounting) disclosures on capital markets. We know from the prior literature that higher quality and less opaque, more timely disclosures are generally rewarded by capital markets with higher share prices, lower cost of equity capital and of long-term debt, greater levels of analyst following, and lower bid-ask spreads (Barth et al., 2013; Francis et al., 2005; Francis et al., 2008; Lang et al., 2012; Lang and Lundholm, 1996; Matsumara et al., 2014). Given the difficulty of measuring the quality of an integrated report, questions could arise around what the chosen IR proxy actually measures. Firstly, does it provide a good representation of the quality of IR? Secondly, does it measure only the quality of IR, or does it also reflect elements of good accounting disclosure in general?

Given these questions, IR studies should control for general accounting quality, especially disclosure quality, and the control(s) must be convincing. Conventional accounting quality controls, such as proxies for earnings management, is not sufficient. We suggest that it is necessary to control for the amount (and/or quality) of additional information firms already disclose via channels other than their integrated report.

In order to answer questions around whether a disclosure proxy is really about disclosure and not merely a proxy for information already known to the market, it is necessary to control for 
the underlying performance. Because IR disclosures include (relevant) social and environmental information, this issue is important, especially considering that there is still uncertainty about whether CSR performance and disclosure are positively or negatively associated. Positive associations are commonly hypothesised, and have been documented, in the voluntary disclosure literature; negative associations are commonly hypothesised, and have been found, in the environmental disclosure literature. CSR performance can be seen as a means to manage the risk of environmental disaster and loss of reputation. Therefore, we advise including a control variable that can serve as a proxy for a firm's CSR performance.

Many firms that issue an integrated report continue to disclose CSR information via other media, such as standalone CSR reports, or their websites (Massa et al., 2015). Dhaliwal et al. (2011) show that firms with high cost of equity capital are more likely to publish a standalone CSR report and, under certain conditions, are subsequently rewarded with a lower cost of capital. Dhaliwal et al. (2014) report a negative association between the issuance of a standalone CSR report and the cost of equity capital in an international setting, and Dhaliwal et al. (2012) show a negative association between the issuance of a standalone CSR report and analysts' forecast errors. These studies suggest that it is appropriate to include a control variable for the issuance of a standalone CSR report, or for the amount/quality of CSR information disclosed through other means, in the regression model of an IR study.

The individual items included in an IR coding framework will not apply equally to all firms. For example, firms in the financial sector are less affected by environmental issues than mining firms. This underscores the importance of controlling for industry in an IR study. In economics-based IR research, questions often arise around endogeneity. Endogeneity includes three different issues: correlated omitted variables, simultaneity, and reverse causality (Larcker and Rusticus, 2010; Nikolaev and Van Lent, 2005). Where unobservable 
omitted variables are a concern, researchers should consider changes specifications. Selfselection is an example of unobservable omitted variables, and is a feature of IR settings where factors affecting the voluntary decision to present an integrated report are interconnected with economic consequences (the dependent variable). Where managers can choose whether or not to issue an integrated report, a two-stage selection model is needed, in which the predictors of the IR choice are modelled in the first stage, and a control (such as the inverse Mills ratio) is added for this choice in the second stage (see Lennox et al., 2011).

Simultaneity implies that IRQ has economic consequences (for example, profitability) and, at the same time, profitability causes managers to adjust IRQ. By contrast, reverse causality implies that a researcher's arguments or theories on why IRQ affects economic consequences are not solid, whereas the arguments for reverse causality are stronger. Several approaches can be used to address these concerns. For example, Dhaliwal et al. (2011) implement a leadlag approach and focus on when firms issue a report for the first time. Larcker and Rusticus (2010) provide examples of using instrumental variables to address endogeneity concerns, while Gippel et al. (2015) focus on natural experiments as a possible solution.

\section{Agenda for future research}

The IIRC's framework sets out the primary purpose of an integrated report to "explain to providers of financial capital how an organization creates value over time" (IIRC, 2013, p. 7), and states that IR aims to "improve the quality of information available to providers of financial capital to enable more efficient and productive allocation of capital" (IIRC, 2013, p. 2). These and other claims in the IR framework can be investigated by means of economics-based methods.

Most firms that disclose an integrated report do so voluntarily, but there are exceptions. For example, in South Africa, firms with a primary listing on the JSE must publish an integrated 
report, or explain why they choose not to do so. Arguably this makes it optional for JSElisted firms to publish an integrated report, but, as King III indicates, the "apply or explain" approach means "it is not a case of whether to comply or not, but rather to consider how the principles and recommendations can be applied" (IoD, 2009, p. 6). Nevertheless, even under such "mandatory" regulations, firms can choose the extent of their compliance with the rules (Peters and Romi, 2013), especially given that the IR framework is principles-based. Therefore, IRQ will still vary, even in a mandatory setting.

This implies that many of the approaches prevalent in the voluntary disclosure literature, and the voluntary and the mandatory IFRS adoption literature, can be applied to IR research. ${ }^{7}$ Assessing the association between IR adoption (or IRQ) and the following outcomes could be of interest to firms and regulators:

- Firm value (for example, share price and Tobin's Q);

- Firm performance (for example, future profitability and cash flows);

- Cost of equity capital;

- Cost of debt capital;

- Information environment (for example, analyst following); and

- Liquidity (for example, bid-ask spread, zero-return days, share turnover, and price impact).

Given the IR framework's emphasis on disclosing how a firm's strategy is reflected in its business model, managers and boards of directors could change their views and start to see the business and its long-term prospects in a different light. This is linked to the concept of “integrated thinking”. The IIRC (2013) describes IR as a process founded on integrated thinking. Hence, the IIRC envisages that the process of preparing an integrated report will affect managers' internal decisions by directing them to focus more on the firm's long-term sustainability than on its short-term financial performance. Academic researchers could test these claims. Questions to explore include whether IR adoption (or IRQ) is associated with

\footnotetext{
${ }^{7}$ Healy and Palepu (2001) review the voluntary disclosure literature and Pope and McLeay (2011) review the IFRS adoption literature.
} 
- Lower levels of accruals-based earnings management;

- Lower levels of real activities earnings management;

- Lower levels of tax avoidance; and

- Investment and financing decision outcomes.

In addition, board characteristics can be examined as a determinant of IR (Mey and de Klerk, 2015).

Serafeim (2015) undertook an initial assessment of the association between IR and investor clientele, but more work is warranted on this topic. Globally, several responsible investment initiatives have recently developed, such as the United Nations Principles for Responsible Investment (UN PRI), the Global Sustainable Investment Alliance (GSIA), and the Code for Responsible Investing in South Africa (CRISA). Empirical evidence is still needed on whether firms that practise IR attract more of the signatories of these responsible investor codes, or alternatively whether these signatories (investors) increase pressure on the firms they invest in to practise high quality IR.

There is evidence that the relationship between non-financial disclosures and economic consequences are influenced by national culture (Khlif et al., 2015; Maroun, 2015), suggesting a need for IR studies in multiple countries.

Further research around the impact of IR assurance would be of interest to the accounting profession and to managers considering IR assurance for their firms. In particular, little is known about which assurance practices (or combination of practices), if any, are most effective in signalling and improving the quality of integrated reports. Therefore, interesting research projects could be developed using various measures of IR assurance instead of, or in combination with, the measure of IRQ to test these ideas. 
As with other archival studies, researchers could enrich their analysis by honing in on crosssectional differences where the effect of IR could be most pronounced. Such studies could focus on firms with high managerial incentives to produce high quality integrated reports, or on specific industries where IR is more relevant.

Up to this point, we have focused on the economic benefits associated with IR, which can best be examined using economics-based archival methods. We now turn to how investors react to various forms and formats of IR, how organizations adapt internally to cope with the demands of IR, and how the field of IR is developed by the accounting profession and by the IIRC. Some of these questions could also be examined using archival economics-based methods. However, we now turn to other methods.

Experimental researchers can study several important IR research questions, unhampered by archival data limitations. Because experimental researchers can control the manipulations in the experiment, such studies can provide stronger tests of theory and causation than archival studies. Experiments also allow an exploration of IR disclosure methods/formats/options not often encountered in practice, whereas archival researchers are limited to methods/formats/options currently in use. Therefore, the way investors react to various formats of, and information in, IR can be explored through experiments. Experimental designs are well suited to address questions such as:

- Do investors/analysts change their capital allocation decisions/recommendations in response to various formats of integrated reports and the information provided in them? If so, how and to what extent?

- Do users of integrated reports change their capital allocation decisions based on the level of integratedness of firms' integrated reports? If so, how and to what extent? 
- Do managers change their resource allocation decisions depending on the level of integratedness of firms' internal management reports? If so, how and to what extent?

The research opportunities around the internal processes in organizations when they initiate IR can best be explored using qualitative research methods, such as case studies, to answer questions such as the following:

- How does initiating IR alter management control systems, top management thinking, strategy, business models, etc.?

- How are firms transformed internally when they embark on IR?

In addition, qualitative methods are well suited to answer broader questions around developments in the field of IR, such as the following:

- How does the accounting profession use IR to advance the practice?

- How does the IIRC promote its agenda? Which mechanisms are the most effective?

- Taking a historical approach, as advocated by Parker (2015), what can be learnt from the development of IR for current and future practice?

Researchers could use the approaches and questions we propose here as a starting point to develop their research projects.

\section{Conclusion}

Integrated reporting represents a new corporate disclosure philosophy that focuses on providing future value creation information, related to the firm's strategy and business model, and the six capitals (financial, manufactured, intellectual, human, social and relationship, and natural capital), to financial stakeholders. IR is widely promoted by the IIRC, and several other bodies, including the accounting profession, who see it as a source of new business. The 
broad promotion and adoption of IR provides the kind of natural experimental setting that can be used to answer several types of interesting research questions.

In this paper, we provide background, discuss the prior literature and highlight research opportunities in IR. We identify and discuss broad research approaches and questions, measurement issues, control variables to consider, and other research design considerations. This paper goes beyond prior overview and agenda setting articles by classifying the IR literature into themes that can be used in future research to gain further insights. In addition, the paper discusses IR measurement issues more comprehensively. For example, the paper deals with the issue of how to determine whether a firm uses IR, how to measure the quality of an integrated report, possible control measures to include, and other research design issues to consider to address the threat of endogeneity to the interpretation of the results.

We have no doubt that integrated reporting will prove to be fertile ground for future research. 


\section{References}

Abeysekera, I., 2013, A template for integrated reporting, Journal of Intellectual Capital $14(2), 227-245$.

Adams, C.A., 2015, The International Integrated Reporting Council: a call to action, Critical Perspectives on Accounting 27, 23-28.

Adams, S., and R. Simnett, 2011, Integrated Reporting: an opportunity for Australia's notfor-profit sector, Australian Accounting Review 21(3), 292-301.

Arguelles, M.P.M., M. Balatbat, and W. Green, 2015, Is there an early-mover market value effect for signalling adoption of integrated reporting? Working paper (University of New South Wales).

Atkins, J., and W. Maroun, 2015, Integrated reporting in South Africa in 2012: perspectives from South African institutional investors, Meditari Accountancy Research 23(2), 197-221.

Atkins, J.F., A. Solomon, S. Norton, and N.L. Joseph, 2015, The emergence of integrated private reporting, Meditari Accountancy Research 23(1), 28-61.

Baboukardos, D., and G. Rimmel, 2016, Value relevance of accounting information under an integrated reporting approach: a research note, Journal of Accounting and Public Policy, in press.

Barth, M.E., S.F. Cahan, L. Chen, and E.R. Venter, 2015, The economic consequences associated with integrated report quality: early evidence from a mandatory setting, Working paper (Stanford University).

Barth, M.E., Y. Konchitchki, and W.R. Landsman, 2013, Cost of capital and earnings transparency, Journal of Accounting and Economics 55, 206-224.

Bernardi, C., and A.W. Stark, 2015, Environmental, social and governance disclosure, integrated reporting, and the accuracy of analyst forecasts, Working paper (University of Manchester).

Brown, J., and J. Dillard, 2014, Integrated reporting: on the need for broadening out and opening up, Accounting, Auditing \& Accountability Journal 27(7), 1120-1156.

Business Standard Reporters, 2014, Sebi wants yearly tell-all accounts, 17 September. Available at: http://www.business-standard.com/article/markets/sebi-wants-yearlytell-all-accounts-114091701199_1.html.

Business 20 (B20), 2014, Unlocking investment in infrastructure: is current accounting and reporting a barrier? June. Available at: http://www.kpmg.com/Global/en/ IssuesAndInsights/ArticlesPublications/Press-releases/Documents/unlockinginvestment-in-infrastructure.pdf.

Cheng, M., W. Green, P. Conradie, N. Konishi, and A. Romi, 2014, The International Integrated Reporting Framework: key issues and future research opportunities, Journal of International Financial Management \& Accounting 25(1), 90-119.

Churet, C., and R. G. Eccles, 2014, Integrated Reporting, quality of management, and financial performance, Journal of Applied Corporate Finance 26(1), 56-64.

Corporate Reporting Dialogue, 2015, Navigating the corporate reporting landscape. Available at: http://corporatereportingdialogue.com/wp-content/uploads/2015/05/CRD-Mapping -Document_website_070515.pdf.

De Villiers, C., L. Rinaldi, and J. Unerman, 2014, Integrated reporting: insights, gaps and an agenda for future research, Accounting, Auditing \& Accountability Journal 27(7), 1042-1067.

De Villiers, C., and C. van Staden, 2011, Where firms choose to disclose voluntary environmental information, Journal of Accounting and Public Policy 30(6), 504-525. 
Dhaliwal, D.S., O.Z. Li, A. Tsang, and Y.G. Yang, 2011, Voluntary nonfinancial disclosure and the cost of equity capital: the initiation of Corporate Social Responsibility Reporting, The Accounting Review 86(1), 59-100.

Dhaliwal, D.S., O.Z. Li, A. Tsang, and Y.G. Yang, 2014, Corporate social responsibility disclosure and the cost of equity capital: the roles of stakeholder orientation and financial transparency, Journal of Accounting and Public Policy 33, 328-355.

Dhaliwal, D.S., S. Radhakrishnan, A. Tsang, and Y.G. Yang, 2012, Nonfinancial disclosure and analyst forecast accuracy: international evidence on corporate social responsibility disclosure, The Accounting Review 87(3), 723-759.

Easton, P., 2004, PE Ratios, PEG ratios, and estimating the implied expected rate of return on equity capital, The Accounting Review 79, 73-95.

Eccles, R.G., and M. Krzus, 2010, One Report: Integrated Reporting for a Sustainable Strategy (Wiley, Hoboken NJ).

Eccles, R.G., M. Krzus, and S. Ribot, 2015, Models of best practice in integrated reporting 2015, Journal of Applied Corporate Finance 27(2), 103-115.

Eccles, R.G., and D. Saltzman, 2011, Achieving sustainability through integrated reporting, Stanford Social Innovation Review 9(3), 56-61.

Eccles, R.G., and G. Serafeim, 2011, Accelerating the adoption of integrated reporting. In De Leo, F., and M. Vollbracht, CSR Index 2011 (Social Science Research Network, Rochester, NY), 70-92.

EY, 2014, EY's excellence in integrated reporting awards 2014: A survey of the integrated reports from South Africa's top 100 JSE-listed companies and the top 10 state-owned companies (EY, Johannesburg).

European Commission (EC), 2014, Disclosure of non-financial and diversity information by large companies and groups - frequently asked questions. Memo/14/301. Available at: http://europa.eu/rapid/press-release_MEMO-14-301_en.htm.

Fairfield, C., 2016, GE launches integrated summary report, BusinessWire 14 March. Available at: http://www.businesswire.com/news/home/20160314006354/en/GELaunches-Integrated-Summary-Report.

Flower, J., 2015, The International Integrated Reporting Council: A story of failure, Critical Perspectives on Accounting 27, 1-17.

Francis, J.R., I.K. Khurana, and R. Pereira, 2005, Disclosure incentives and effects on cost of capital around the world, The Accounting Review 80(4), 1125-1162.

Francis, J.R., D. Nanda, and P. Olsson, 2008, Voluntary disclosure, earnings quality and cost of capital, Journal of Accounting Research 46(1), 53-99.

Frías-Aceituno, J.V., L. Rodríguez-Ariza, and I.M. García-Sánchez, 2013, Is integrated reporting determined by a country's legal system? An exploratory study, Journal of Cleaner Production 44, 45-55.

García-Sánchez, I.M., L. Rodríguez-Ariza, and J.V. Frías-Aceituno, 2013, The cultural system and integrated reporting, International Business Review 22(5), 828-838.

Gippel, J., T. Smith, and Y. Zhu, 2015, Endogeneity in accounting and finance research: Natural experiments as a state-of-the-art solution, Abacus 51(2), 143-168.

Hay, D., 2015, The frontiers of auditing research, Meditari Accountancy Research 23(2), 158-174.

Healy, P.M., and K.G. Palepu, 2001, Information asymmetry, corporate disclosure, and the capital markets: a review of the empirical disclosure literature, Journal of Accounting and Economics 31, 405-440.

Higgins, C., W. Stubbs, and T. Love, 2014, Walking the talk(s): organisational narratives of integrated reporting, Accounting, Auditing \& Accountability Journal 27(7), 1090-1119. 
Humphrey, C., B. O'Dwyer, and J. Unerman, 2016, Re-theorizing the configuration of organizational fields: the IIRC and the pursuit of "enlightened" corporate reporting, Accounting and Business Research, in press.

Jensen, C., and N. Berg, 2012, Determinants of traditional sustainability reporting versus integrated reporting: an institutionalist approach, Business Strategy and the Environment 21(5), 299-316.

Kee, H.Y., M. Larsen, and T.B. Seng, 2014, Should Singapore firms adopt Integrated Reporting? The Business Times 13 March, 22.

Khlif, H., K. Hussainey, and I. Achek, 2015, The effect of national culture on the association between profitability and corporate social and environmental disclosure: a metaanalysis, Meditari Accountancy Research 23(3), 296-321.

Kitney, D., 2014, Super funds enthusiastic about reporting regime, The Australian 15 July.

Knauer, A., and G. Serafeim, 2014, Attracting long-term investors through integrated thinking and reporting: A clinical study of a biopharmaceutical company, Journal of Applied Corporate Finance 26(2), 57-64.

Krzus, M.P., 2011, Integrated reporting: if not now, when?, IRZ-Zeitschrift für Internationale Rechnungslegung 6, 271-276.

Lang, M., K.V. Lins, and M. Maffett, 2012, Transparency, liquidity, and valuation: international evidence on when transparency matters most, Journal of Accounting Research 50(3), 729-774.

Lang, M. and R.J. Lundholm, 1996, Corporate disclosure policy and analyst behavior, The Accounting Review 71(4), 467-492.

Larcker, D.F., and T.O. Rusticus, 2010, On the use of instrumental variables in accounting research, Journal of Accounting and Economics 49, 186-205.

Lee, K., and G.H. Yeo, 2015, The association between integrated reporting and firm valuation, Review of Quantitative Finance and Accounting, in press.

Lennox, C.S., J.R. Francis, and Z. Wang, 2011, Selection models in accounting research, The Accounting Review 87(2), 589-616.

Lodhia, S. 2015, Exploring the transition to integrated reporting through a practice lens: an Australian customer owned bank perspective, Journal of Business Ethics 129, 585598.

Maniora, J., 2015, Is integrated reporting really the superior mechanism for the integration of ethics into the core business model? An empirical analysis, Journal of Business Ethics, in press.

Maroun, W., 2015, Culture, profitability, non-financial reporting and a meta-analysis: comments and observations, Meditari Accountancy Research 23(3), 322-330.

Massa, L., F. Farneti, and B. Scappini, 2015, Developing a sustainability report in a small to medium enterprise: process and consequences. Meditari Accountancy Research 23(1), 62-91.

Matsumura, E.M., R. Prakash, and S.C. Vera-Munoz, 2014, Firm-value effects of carbon emissions and carbon disclosures, The Accounting Review 89(2), 695-724.

Mey, E. and M. de Klerk, 2015, Association between having a CA (SA) as CEO and accruals quality, Meditari Accountancy Research 23(3), 276-295.

Nikolaev, V. and L. van Lent, 2005, The endogeneity bias in the relation between cost-ofdebt capital and corporate disclosure policy, European Accounting Review 14(4), 677-724.

Parker, L., 2015, Accounting historiography: looking back to the future, Meditari Accountancy Research 23(2), 142-157. 
Parrot, K.W., and B.X. Tierney, 2012, Integrated reporting, stakeholder engagement, and balanced investing at American Electric Power, Journal of Applied Corporate Finance 24(2), 27-37.

Peters, G.F., and A.M. Romi, 2013, Discretionary compliance with mandatory environmental disclosures, Journal of Accounting and Public Policy 32, 213-236.

Pope, P.F., and S.J. McLeay, 2011, The European IFRS experiment: objectives, research challenges and some early evidence, Accounting and Business Research 41(3), 233266.

Rambaud, A., and J. Richard, 2015, The "Triple Depreciation Line" instead of the "Triple Bottom Line": towards a genuine integrated reporting, Critical Perspectives on Accounting 33, 92-116.

Reuter, M., and M. Messner, 2015, Lobbying on the integrated reporting framework: an analysis of comment letters to the 2011 discussion paper of the IIRC, Accounting, Auditing \& Accountability Journal 28(3), 365-402.

Rowbottom, N., and J. Locke, 2016, The emergence of IR, Accounting and Business Research 46, 83-115.

Serafeim, G., 2015, Integrated reporting and investor clientele, Journal of Applied Corporate Finance 27, 34-51.

Solomon, J., and W. Maroun, 2012, Integrated reporting: the influence of King III on social, ethical and environmental reporting (ACCA, London).

Stent, W., and T. Dowler, 2015, Early assessments of the gap between integrated reporting and current corporate reporting, Meditari Accountancy Research 23(1), 92-117.

Stubbs, W., and C. Higgins, 2014, Integrated Reporting and internal mechanisms of change, Accounting, Auditing \& Accountability Journal 27(7), 1068-1089.

Thomson, I., 2015, "But does sustainability need capitalism or an integrated report" a commentary on "The International Integrated Reporting Council: A story of failure" by Flower, J, Critical Perspectives on Accounting 27, 18-22.

Van Bommel, K., 2014, Towards a legitimate compromise? An exploration of Integrated Reporting in the Netherlands, Accounting, Auditing \& Accountability Journal 27(7), 1157-1189.

Zhou, S., R. Simnett, and W. Green, 2016, Does integrated reporting matter to the capital market? Abacus, in press.

Zhou, S., R. Simnett, and H. Hoang, 2016, Combined assurance as a new assurance approach: is it beneficial to analysts? Working paper (University of Sydney). 
Appendix 1

\begin{tabular}{|c|c|}
\hline CGVS & CORPORATE GOVERNANCE: VISION AND STRATEGY \\
\hline \multicolumn{2}{|l|}{ DRIVERS (D) } \\
\hline CGVSD01 & $\begin{array}{l}\text { Does the company have a policy for maintaining an overarching vision and strategy } \\
\text { that integrates financial and extra-financial aspects of its business? }\end{array}$ \\
\hline CGVSDP011 & $\begin{array}{l}\text { Does the company have a policy to integrate ESG issues into its strategy and day-to- } \\
\text { day decision making? }\end{array}$ \\
\hline CGVSD02 & $\begin{array}{l}\text { Does the company describe the implementation of its integrated strategy through a } \\
\text { public commitment from a senior management or board member? AND Does the } \\
\text { company describe the implementation of its integrated strategy through the } \\
\text { establishment of a CSR committee or team? }\end{array}$ \\
\hline CGVSDP0041 & $\begin{array}{l}\text { Has there been a public commitment from a senior management or board member to } \\
\text { integrate ESG issues into the company strategy and day-to-day decision making? }\end{array}$ \\
\hline CGVSDP005 & Does the company have a CSR committee or team? \\
\hline CGVSD03 & $\begin{array}{l}\text { Does the company monitor its integrated strategy through belonging to a specific } \\
\text { sustainability index? AND Does the company monitor its integrated strategy through } \\
\text { conducting external audits on its reporting? }\end{array}$ \\
\hline CGVSDP013 & Does the company report on belonging to a specific sustainability index? \\
\hline CGVSDP030 & Does the company have an external auditor of its CSR/H\&S/Sustainability report? \\
\hline CGVSD04 & Does the company set specific objectives to be achieved on the integrated strategy? \\
\hline CGVSDP0141 & $\begin{array}{l}\text { Has the company set targets or objectives to be achieved on the integration of ESG } \\
\text { issues into its strategy and day-to-day decision making? }\end{array}$ \\
\hline \multicolumn{2}{|c|}{ OUTCOMES (O) } \\
\hline CGVSO01 & $\begin{array}{l}\text { Does the company report about the challenges or opportunities linked to the } \\
\text { integration of financial and extra-financial issues? }\end{array}$ \\
\hline CGVSDP016 & $\begin{array}{l}\text { Is the company openly reporting about the challenges or opportunities of integrating } \\
\text { financial and extra-financial issues, and the dilemmas and trade-offs it faces? }\end{array}$ \\
\hline CGVSO02 & $\begin{array}{l}\text { Does the company integrate financial and extra-financial factors in the management } \\
\text { discussion and analysis section of the annual report? }\end{array}$ \\
\hline CGVSDP018 & $\begin{array}{l}\text { Does the company explicitly integrate financial and extra-financial factors in its } \\
\text { management discussion and analysis (MD\&A) section in the annual report? }\end{array}$ \\
\hline CGVSO03 & Is the company a signatory of the Global Compact? \\
\hline CGVSDP020 & Has the company signed the UN Global Compact? \\
\hline CGVSO04 & Does the company explain how it engages with its stakeholders? \\
\hline CGVSDP023 & Does the company explain how it engages with its stakeholders? \\
\hline CGVSO05 & $\begin{array}{l}\text { Does the company publish a separate CSR/H\&S/Sustainability report or publish a } \\
\text { section in its annual report on CSR/H\&S/Sustainability? }\end{array}$ \\
\hline CGVSDP026 & $\begin{array}{l}\text { Does the company publish a separate CSR/H\&S/Sustainability report or publish a } \\
\text { section in its annual report on CSR/H\&S/Sustainability? }\end{array}$ \\
\hline CGVSO06 & Is the company's CSR report published in accordance with the GRI guidelines? \\
\hline CGVSDP028 & Is the company's CSR report published in accordance with the GRI guidelines? \\
\hline CGVSO07 & $\begin{array}{l}\text { Does the company's extra-financial report take into account of the global activities } \\
\text { of the company? }\end{array}$ \\
\hline CGVSDP029 & $\begin{array}{l}\text { Does the company's extra-financial report take into account the global activities of the } \\
\text { company? }\end{array}$ \\
\hline CGVSO08 & Does the company have an external auditor of its $C S R / H \& S / S u s t a i n a b i l i t y ~ r e p o r t ?$ \\
\hline CGVSDP030 & Does the company have an external auditor of its CSR/H\&S/Sustainability report? \\
\hline
\end{tabular}

